\title{
Harmonisasi Pengaturan Pelindungan Logo Menurut Hukum Merek dan Hak Cipta Dalam Perspektif Perbandingan di Indonesia dan Thailand
}

\author{
Ika Citra Dewi, Miranda Risang Ayu Palar, Muhamad Amirulloh \\ Fakultas Hukum Universitas Padjajaran \\ ika19001@mail.unpad.ac.id
}

Submit: 14-08-2020; Review: 16-11-2020; Terbit: 28-11-2020

\begin{abstract}
This article analyses regarding the harmonization of logo's protection regulation according to the trademark and copyright law in the comparative perspective in Indonesia and Thailand. The overlap between substantive examination regulations on intellectual property objects in the form of logos according to the perspective of trademark law and copyright creates legal uncertainty so that in-depth research is required to examine how to arrange logos in the perspective of trademark and copyright law in Indonesia and Thailand and how to arrange the "MIFFY" logo case in Thailand in the perspective of law in Indonesia as one representation of the case of copyright logos that are registered on the basis of an imitation/plagiarism of logos protected in the trademark. In this research, the form of research used is normative legal research. By comparing the legal concept between Indonesia and Thailand, it will aim to streamline and optimize the protection of the logo.Thus, there needs to be an effort to harmonize logo arrangements in the perspective of trademark and copyright law in Indonesia to realize harmonious intellectual property laws, appropriate so as to realize justice and legal certainty.
\end{abstract}

\section{Keywords: harmonization; logo; trademark; copyright; legal comparison}

\begin{abstract}
Abstrak
Artikel ini menganalisis tentang harmonisasi pengaturan pelindungan logo menurut hukum merek dan hak cipta dalam perspektif perbandingan di Indonesia dan Thailand. Adanya tumpang tindih antara pengaturan pemeriksaan substantif terhadap obyek kekayaan intelektual dalam bentuk logo menurut perspektif hukum merek dan hak cipta menimbulkan ketidakpastian hukum sehingga diperlukan penelitian mendalam yang mengkaji bagaimana pengaturan logo dalam perspektif hukum merek dan hak cipta di negara Indonesia dan Thailand serta bagaimana pengaturan kasus logo "MIFFY" di Thailand dalam perspektif hukum di Indonesia sebagai salah satu representasi dari kasus logo/lukisan hak cipta yang dicatatkan atas dasar tiruan/jiplakan dari lukisan yang dilindungi dalam merek dagang. Dalam penelitian ini, bentuk penelitian yang digunakan adalah penelitian hukum normatif. Dengan memperbandingkan konsep hukum antara negara Indonesia dan Thailand, maka akan bertujuan untuk mengefisiensikan dan mengoptimalkan pelindungan logo tersebut Dengan demikian, perlu adanya suatu upaya harmonisasi pengaturan logo dalam perspektif hukum merek dan hak cipta di Indonesia untuk mewujudkan peraturan perundang-undangan kekayaan intelektual yang selaras, sesuai sehingga mewujudkan keadilan dan kepastian hukum.
\end{abstract}


Kata Kunci: harmonisasi, logo, merek, hak cipta, perbandingan hukum.

\section{Pendahuluan}

Merek dagang sudah ada di dunia kuno. Selama 3.000 bertahun-tahun yang lalu, pengrajin India biasa mengukir tanda tangan mereka pada kreasi artistik mereka sebelum mengirimnya ke Iran. Merek dagang mulai memainkan peran penting dalam industrialisasi, dan sejak itu merek dagang menjadi faktor kunci dalam dunia modern perdagangan internasional dan ekonomi berorientasi pasar. Industrialisasi dan pertumbuhan sistem ekonomi berorientasi pasar memungkinkan produsen dan pedagang bersaing untuk menawarkan konsumen berbagai barang dalam kategori yang sama (World Intellectual Property Organization, 1993: 9).

Pada saat ini, menggunakan nama, logo, simbol, dan atribut lainnya, yang unik dan bernilai, tetapi mudah untuk diingat konsumen serta menyesuaikan dengan konsumen yang menjadi target dari suatu produsen sangat disarankan mengingat pada saat ini konsumen dibanjiri oleh produk sehingga kemudahan bagi konsumen dalam mengingat suatu merek menjadi penting, agar tidak mudah dilupakan oleh konsumen (Sugianto Yasir; Machasin; Rambat Lupiyoadi, 2009: $68)$.

Banyak produsen yang menonjolkan logo dalam kemasan produk barang atau jasanya. Membuat, dan membangun sebuah logo dan penamaan merek memerlukan waktu yang tidak sedikit dan pengorbanan biaya yang tidak murah. Oleh karenanya, banyak pula pihak-pihak yang mengambil keuntungan dalam hal ini menggunakan logo milik pihak lain yang telah dikenal dan dilindungi dalam rezim hukum merek dan/atau hak cipta. Pengaturan terkait logo yang jelas sebagai suatu karya intelektual belum diakomodasi dalam Undang-Undang Nomor 20 Tahun 2016 tentang Merek dan Indikasi Geografis (UUMIG), sehingga dapat menimbulkan tumpang tindih menurut perspektif hukum merek dan hak cipta. Oleh karenanya, perlu adanya harmonisasi pengaturan pelindungan logo untuk menciptakan 
adanya kepastian hukum bagi para pemilik atau pemegang merek.

Setidaknya terdapat 3 (tiga) tulisan yang membahas tentang persinggungan hak cipta dan merek di Indonesia. Pertama, tulisan yang berjudul "Persinggungan Hak Cipta Dan Merek: Studi Kasus Sengketa Logo Badak Dan Sengketa Logo Natasha" oleh Boy Prawiranegara dan Agus Sardjono. Di dalamnya membahas tentang pelindungan ganda yang dimungkinkan terhadap logo yang dijadikan merek namun penerapannya haruslah melihat kembali kepentingan sebenarnya dibalik klaim yang diajukan penggugat dengan studi kasus sengketa logo badak dan sengketa logo natasha. Dari penelitian tersebut disimpulkan bahwa jika ingin melindungi sebuah Ciptaan dari tindakan yang melanggar hak eksklusif seseorang atas sebuah Ciptaan (baik hak ekonomi maupun moral) maka gunakanlah pelindungan hak cipta. Namun gunakanlah pelindungan merek apabila yang ingin dilindungi adalah sebuah produk (barang maupun jasa) produk tersebut (Boy Prawiranegara dan Agus Sardjono, 2013: 13-17).
Kemudian, yang kedua adalah tulisan yang membahas tentang Penyelesaian Sengketa Hak Atas Logo (Suatu Kajian Overlapping Hak Cipta dan Merek) yang ditulis oleh Muchtar AH Labetubun, Fakultas Hukum Universitas Pattimura, Ambon. Tulisan tersebut berfokus pada "logo" dilihat dari aspek hak cipta dengan merek ada kesamaan, hal ini dapat dikatakan bahwa kurangnya pemahaman mengenai perbedaan antara pelindungan Hak Cipta dan Merek menyebabkan munculnya sengketa Hak Cipta yang sesungguhnya merupakan sengketa Merek. Tumpang tindih klaim atas logo yang terjadi dalam perkara merek di Pengadilan Niaga, menandakan bahwa kepemilikan suatu logo berpotensi atas dualisme hak atas logo, hal ini disebabkan karena perbedaan proses pendaftaran yang berbeda. Pemeriksaan substantif tidak dikenal dalam proses pendaftaran hak cipta, sehingga ciptaan tersebut mendapatkan sertifikat dengan mudah. Pendaftaran hak cipta juga dipermudah karena dalam konsep hukum hak cipta, pendaftaran tidak menimbulkan hak. Hal ini berbeda dengan merek karena 
menganut istilah first to file principle dimana pihak yang pertama kali mendaftarkan diakui sebagai pemegang hak merek atas merek (Muchtar AH Labetubun, 2019: 151166).

Selanjutnya, yang ketiga adalah tulisan yang membahas tentang Pengaturan Pelindungan Hukum Logo Bank Sebagai Merek Dalam Laman Perdagangan Dengan Menggunakan Multimedia Elektronik Berdasarkan Undang-Undang Nomor 20 Tahun 2016 tentang Merek dan Indikasi Geografis dan UndangUndang Nomor 11 Tahun 2008 tentang Informasi dan Transaksi Elektronik yang ditulis oleh Handi Hermawan. Tulisan tersebut berfokus pada pelindungan hukum logo bank sebagai merek yang digunakan dalam laman perdagangan perjudian bola online. Logo-logo bank tersebut digunakan oleh pihak lain yang bertujuan untuk menginformasikan kepada konsumen perjudian online bahwa pihak laman perdagangan menyediakan platform transfer pembayaran melalui rekening dari masing-masing logo bank tersebut (studi kasus yang ada dalam penelitian adalah bank BCA, bank
BNI46 dan bank Mandiri) (Handi Hermawan, 2017: 55-60).

Dari ketiga tulisan tersebut di atas, tulisan pertama dan kedua membahas adanya persinggungan logo dalam perspektif hukum merek dan hak cipta namun belum ada satupun dari kedua penulisan tersebut yang menggambarkan inti pokok permasalahan yang menyebabkan terjadinya tumpang tindih logo. Sedangkan, pada tulisan ketiga membahas tentang pengaturan pelindungan logo bank sebagai merek yang digunakan oleh pihak lain dalam laman perdagangan menggunakan multimedia elektronik seperti laman perjudian bola online. Dan, dalam hal ini peneliti tidak sependapat dengan tulisan kedua yang mana menyatakan bahwa pemeriksaan substantif tidak dikenal dalam proses pendaftaran hak cipta.

Dalam penelitian saat ini lebih menekankan pada perlunya mengharmonisasikan pengaturan logo sebagai suatu karya intelektual menurut hukum merek dan hak cipta dalam perspektif perbandingan dengan hukum di Thailand. Perbandingan ini dimaksudkan untuk mengungkapkan dan membandingkan 
latar belakang terjadinya putusan atas perkara dalam bidang yang sama dari negara-negara tersebut dan kemudian akan digunakan sebagai rekomendasi bagi penyusunan atau perubahan aturan hukum yang berlaku di Indonesia. Sehingga, dapat memberikan saran kepada para pembentuk undangundang yakni Dewan Perwakilan Rakyat Republik Indonesia, Pemerintah Republik Indonesia, Pelaku Usaha dan Para Pencipta, dan para Hakim Niaga serta Mahkamah Agung untuk dapat digunakan sebagai dasar pertimbangan putusannya sehingga dapat lebih menjamin kepastian hukum bagi para pemilik, dan pemegang merek sehingga bersesuaian dengan cita-cita negara hukum, khususnya UUMIG.

Untuk itu, pokok permasalahan dari penelitian ini akan berfokus kepada 2 (dua) hal, Pertama, bagaimanakah pengaturan pelindungan logo ditinjau dari hukum merek dan hak cipta di Indonesia dan Thailand? Kedua, bagaimanakah pengaturan kasus logo "Miffy" di Thailand dalam perspektif hukum di Indonesia?
Dalam penelitian ini, bentuk penelitian yang digunakan adalah penelitian hukum normatif. Dalam penelitian hukum normatif ini yang diteliti hanya data pustaka atau data sekunder, yang mungkin mencakup bahan hukum primer, sekunder dan tertier. Penelitian hukum normatif atau kepustakaan tersebut mencakup (Soekanto, 2015: 12-15):

a) Penelitian terhadap asas-asas hukum

b) Penelitian terhadap sistematik hukum

c) Penelitian terhadap taraf sinkronisasi vertikal dan horisontal

d) Perbandingan hukum

e) Sejarah hukum

Data yang digunakan dalam penelitian ini adalah data sekunder yang diperoleh dari (Soekanto, 2015: 1215):

1) Bahan Hukum Primer

2) Bahan Hukum Sekunder

3) Bahan Hukum Tersier

Data yang akan diperoleh selanjutnya dianalisis dengan menggunakan metode penelitian yuridis normatif-kualitatif.

\section{Hasil dan Pembahasan}


Pengaturan pelindungan logo ditinjau dari hukum merek dan hak cipta di Indonesia dan Thailand

Ketatnya persaingan pasar yang memaksa para pelaku bisnis untuk melakukan inovasi dan kreativitas dalam melancarkan strategi bisnis serta pemasaran yang handal untuk merebut pangsa pasar yang telah dikuasasi dengan susah payah. Salah satunya adalah dengan memanfaatkan logo pada suatu kemasan produk ataupun jasa (BisnisUKM, 2014). Logo adalah elemen grafis yang berbentuk ideogram, simbol, emblem, ikon, tanda yang digunakan sebagai lambang sebuah merek (Angela Oscario, 2013: 193).

Dalam bidang desain grafis, logo adalah bagian dari kehidupan seharihari. Logo dapat dilihat di lemari es saat sarapan, di mobil saat berkendara ke kantor, di komputer saat duduk di meja. Ketika ada sesuatu yang ada di mana-mana, Anda mungkin tidak akan memikirkannya. Tetapi logo (dan desain logo) sebenarnya lebih rumit daripada yang disadari kebanyakan orang (Morr, 2018).

Ada tujuh kategori logo (Morr, 2018), yakni:
1) Logo lambang (emblem logo) : sebuah logo lambang terdiri dari huruf yang berada di dalam simbol atau ikon, lencana, segel dan "puncak" atau inti dari lambang tersebut. Logo ini cenderung memiliki tampilan tradisional yang dapat membuat dampak mencolok (Rebecca, 2017). Sebagai contoh: HarleyDavidson Motor Cycles, Harvard Veritas
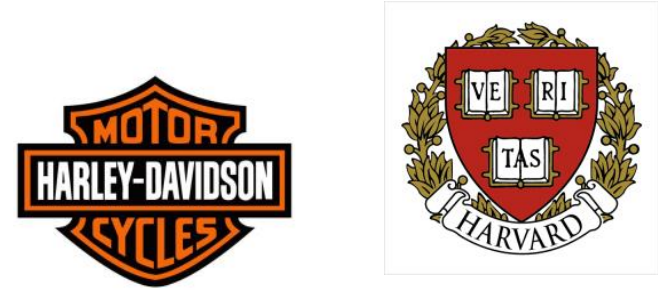

2) Logotypes atau wordmark : juga dikenal sebagai "merek kata", logotypes dibentuk sepenuhnya dari kata atau kata-kata yang merupakan nama perusahaan. Jenis logo ini akan efektif jika perusahaan atau bisnis memiliki nama yang ringkas/sederhana dan unik. Sebagai contoh: Google, Disney, Dell, facebook, FedEx, Microsoft, Coca-Cola 


\section{Google \\ DisNep D시남 facebook. \\ Fed Ex Microsort Cocabola}

3) Logo monogram atau lettermark: jenis logo ini digunakan oleh beberapa merek atau perusahaan seperti HBO, CNN, HP, IBM dan lainnya. Jenis $\log$ ini merepresentasikan kepanjangan dari nama brand terkait. Sebagai contoh:

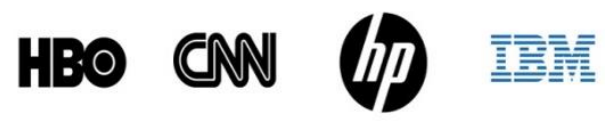

4) Pictorial mark atau simbol : jenis pictorial mark (seringkali disebut sebagai simbol) adalah ikon atau sebuah desain yang berbasis grafis. Sebagai contoh: Twitter, Apple, Nike, WWF
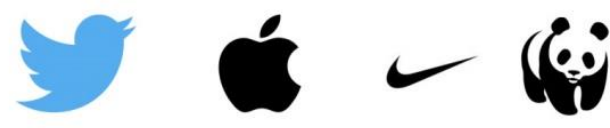

5) Abstrak : logo abstrak adalah jenis tertentu dari pictorial mark/logo simbol (berbasis gambar). Tidak seperti jenis sebelumnya yang mudah dikenali, jenis logo ini memiliki bentuk geometris yang merepresentasikan suatu merek. Sebagai contoh: BP, Pepsi, Adidas
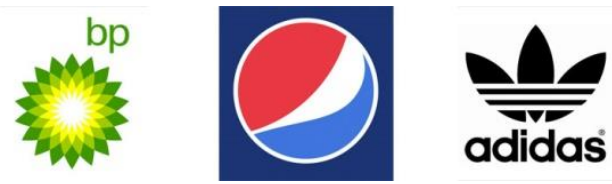

6) Logo maskot: umumnya jenis logo maskot mengandung unsur warna-warni yang menceriakan. Sebagai contoh: Kool-Aid Man by Kool-Aid, KFC, Mr. Peanut by Planters

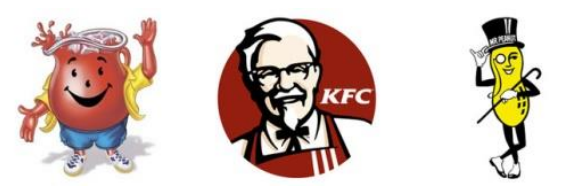

7) Logo kombinasi: sama seperti namanya, logo kombinasi terdiri dari gabungan wordmark atau lettermark dengan logo simbol, abstrak atau maskot. Gambar dan teks bisa disatukan, ditumpuk, atau terintegrasi satu sama lain untuk menciptakan sebuah logo. Sebagai contoh: Adidas, Ihop, Burger King, Microsoft

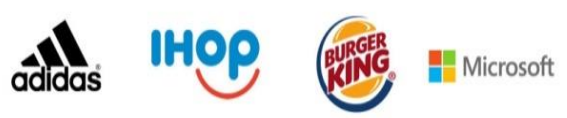


Logo merupakan sebuah simbol yang menggambarkan ciri khas pada produk, hingga citra perusahaan. Logo yang baik mampu mempengaruhi calon konsumen dengan waktu yang singkat. Salah satunya konsumen cukup dengan melihat logo tersebut secara langsung akan menghubungkan dengan suatu produk (Putri Fajrin, 2019).

Di Indonesia, menurut ketentuan perundang-undangan, merek itu sendiri adalah tanda yang dapat ditampilkan secara grafis berupa gambar, logo, nama, kata, huruf, angka, susunan warna, dalam bentuk 2 (dua) dimensi dan/atau 3 (tiga) dimensi, suara, hologram, atau kombinasi dari 2 (dua) atau lebih unsur tersebut untuk membedakan barang dan/atau jasa yang diproduksi oleh orang atau badan hukum dalam kegiatan perdagangan barang dan/atau jasa (Pasal 1 angka 1, UUMIG No. 20 Tahun 2016). Sistem merek itu sendiri memberikan hak eksklusif kepada pemiliknya atas suatu tanda pembeda (Ramli, Ayu Palar, dan Tim Peneliti, 2019: 1). Hak merek bersifat teritorial (yaitu, merek tersebut hanya dilindungi di negara atau wilayah ditempat merek tersebut didaftarkan atau digunakan) (World Intellectual Property Organization, 2018:18).

Menurut UUMIG No. 20 Tahun 2016, merek terdiri dari 2 (dua) macam yakni: (1) merek dagang yang berarti merek yang digunakan pada barang yang diperdagangkan oleh seseorang atau beberapa orang secara bersama-sama atau badan hukum untuk membedakan dengan barang sejenis lainnya; dan (2) merek jasa yang berarti merek yang digunakan pada jasa yang diperdagangkan oleh seseorang atau beberapa orang secara bersama-sama atau badan hukum untuk membedakan dengan jasa sejenis lainnya.

Dikenal beberapa jenis tipe merek, diantaranya yakni (1) merek berupa kata; (2) merek berupa lukisan; (3) merek berupa kata dan lukisan; (4) merek berupa bentuk 3 dimensi; (5) merek berupa suara; dan (6) merek berupa hologram (menurut Keputusan Dirjen Kekayaan Intelektual Nomor HKI-02.HI.06.01 Tahun 2017). Berikut adalah beberapa contoh dari tipe-tipe merek tersebut 
yang sudah terdaftar pada Database

Kantor Ditjen Kekayaan Intelektual

(sumber laman dgip.go.id) :

Tabel 1

Tipe Merek di Indonesia

\begin{tabular}{|c|c|}
\hline Merek Kata & Merek Lukisan \\
\hline adidas & \\
\hline $\begin{array}{c}\text { Merek Kata \& } \\
\text { Lukisan }\end{array}$ & Merek 3D \\
\hline 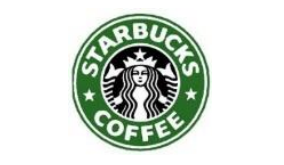 & - \\
\hline Merek Suara & Merek Hologram \\
\hline 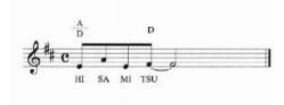 & \\
\hline
\end{tabular}

Selain diatur di dalam ketentuan perundang-undangan, para ahli juga memiliki pandangan serta definisi tentang merek. Menurut Rahmi Jened, merek adalah tanda dengan daya pembeda yang digunakan untuk perdagangan barang dan/atau jasa (Jened, 2017: 6). Menurut Sudargo Gautama (Gautama, 1977: 34), merek adalah alat untuk membedakan barang dan tanda yang dipakai sebagai merek ini kiranya harus mempunyai daya pembedaan untuk dapat membedakan barang yang bersangkutan itu. Menurut David A. Aaker (Aaker, 1991: 21), merek adalah suatu nama dan/atau simbol (seperti logo atau desain kemasan) pembeda yang 
dimaksudkan untuk mengidentifikasi barang atau jasa dari satu penjual atau sekelompok penjual, dan untuk membedakan barang atau jasa tersebut dari kompetitor.

Juga, merek merupakan sebuah nama atau lambang yang digunakan untuk mengidentifikasi suatu produk barang dan jasa sebuah perusahaan di pasaran. Selain itu, merek juga merupakan salah satu bentuk aset harta kekayaan immaterial (Amirulloh dan Novianty Muchtar, 2017: 29-32).

Sedangkan pengertian merek yang diatur dalam ketentuan TRIPs (World Trade Organization) adalah : "Any sign, or any combination of sign, capable of distinguishing the goods or services of one undertaking from those of other undertaking, shall be capable of constituting a trademark. Such sign, in particular word including personal names, letters, numerals, figurative elements and combination of colour as well as any of such sign are not inherenty capable of distinguishing the relevant goods or services, member may make registrability depend on desinctiveness acquired through use. Members may require, as a condition of registration, that signs be visually perceptible".

Terjemahan :

Setiap tanda, atau kombinasi dari beberapa tanda, yang mampu membedakan barang atau jasa dari satu pelaku usaha dengan yang lainnya, dapat menjadi merek dagang. Tanda-tanda tersebut, terutama yang berupa rangkaian kata-kata dari nama pribadi, huruf, angka, unsur figur dan kombinasi dari beberapa warna dapat didaftarkan sebagai merek dagang. Dalam hal suatu tanda tidak dapat membedakan secara jelas beberapa barang atau jasa satu sama lain, Anggota dapat menetapkan persyaratan bagi pendaftarannya pada sifat pembeda yang diperoleh karena penggunaannya. Anggota dapat menetapkan persyaratan, sebagai syarat pendaftaran suatu merek dagang, agar suatu tanda itu dapat dilihat secara visual.

Definisi-definisi tersebut di atas menekankan tujuan identifikasi dan diferensiasi pada penggunaan merek, dimana sebuah merek mengkonfirmasi proteksi hukum yang 
diberikan kepada pemiliknya, mengindikasikan jaminan kualitas, dan memberikan wahanan untuk diferensiasi (Tjiptono, 2014: 90).

Lebih lanjut, berdasarkan beberapa pendapat ahli di atas, penelitian ini menyimpulkan bahwasanya merek adalah suatu penamaan yang dapat berupa tanda, kata, angka, logo atau lukisan, yang berfungsi untuk membedakan suatu produk ataupun jasa satu dengan lainnya yang digunakan dalam kegiatan perdagangan.

Sebagaimana diuraikan di atas, bahwa prinsip permohonan pendaftaran merek di Indonesia menganut sistem konstitutif yang mewajibkan adanya pendaftaran. Pendaftaran merek merupakan alat bukti yang sah atas merek terdaftar. Pendaftaran merek juga berguna sebagai dasar penolakan terhadap merek yang sama keseluruhannya atau sama pada pokoknya yang dimohonkan oleh orang lain untuk barang atau jasa sejenis. Pendaftaran merek sebagai dasar mencegah orang lain memakai merek yang sama pada pokoknya atau secara keseluruhan dalam peredaran barang atau jasa (Mamahit, 2013).
Berdasarkan pengertiannya, obyek yang dilindungi dalam hukum merek adalah tanda yang memiliki daya pembeda dan digunakan untuk kegiatan perdagangan barang dan/atau jasa (Amirulloh dan Novianty Muchtar, 2017: 98).

Saat ini, suatu merek dapat berperan dalam strategi bisnis secara keseluruhan untuk: (Nicolina, 2007: 105-106):

1) Memotivasi orang untuk terlibat/membeli.

2) Menjadikan produk mudah diingat.

3) Menciptakan titik fokus.

4) Menggambarkan hakikat atau fungsi produk.

5) Menciptakan

perasaan/identifikasi yang positif.

Pada hakikatnya, salah satu fungsi merek sebagaimana diuraikan di atas adalah tanda untuk membedakan barang dan/atau jasa yang diproduksi oleh satu pihak dengan pihak lainnya dalam kegiatan perdagangan. Jika suatu tanda tidak dapat membedakan produksi barang dan/atau jasa yang diperdagangkan, maka tanda tersebut tidak dapat berfungsi sebagai merek. Sehingga, 
merek hanya dapat menjalankan fungsinya sebagai pembeda barang dan/atau jasa ketika secara aktual digunakan untuk barang atau jasa di pasaran. Fungsi merek tidak dapat berdiri sendiri atau terlepas dari barang atau jasa yang diperdagangkan (Indriyanto dan Yusnita, 2017: 4858).

Dalam hal pengaturan, hak atas merek di Indonesia ditentukan berdasarkan prinsip "first-to-file" atau "stelsel konstitutif" dan bukan atas dasar "first-to-use" (Tjiptono, 2014: 173-174). Sistem pendaftaran "konstitutif" bermakna yaitu adanya kewajiban pendaftaran bagi pemilik Merek yang ingin memperoleh perlindungan hukum menurut UUMIG (R. Murjiyanto, 2016: 53).

Sedangkan, hak cipta adalah hak eksklusif pencipta yang timbul secara otomatis berdasarkan prinsip deklaratif setelah suatu ciptaan diwujudkan dalam bentuk nyata tanpa mengurangi pembatasan sesuai dengan ketentuan peraturan perundang-undangan (Pasal 1 ayat 1, UUHC No. 28 Tahun 2014). Artinya, dalam arti luas ketentuan kepemilikan suatu Ciptaan tidak ditentukan oleh adanya registrasi karena suatu karya cipta tersebut sudah mendapatkan pelindungan sejak pertama kali diumumkan, namun secara khusus di Indonesia diselenggarakan mekanisme Pendaftaran Ciptaan (Margono, 2012: 1-19).

Pelindungan hak cipta adalah sebagai salah satu tujuan dari diterbitkannya seluruh peraturan hukum tentang hak cipta, termasuk konvensi internasional. Di Indonesia, pelindungan hak cipta telah diatur dalam Undang-Undang Nomor 28 Tahun 2014 tentang Hak Cipta yang menggantikan undang-undang yang lama yaitu Undang-Undang Nomor 19 Tahun 2002 tentang Hak Cipta (Siti Hatikasari, 2018: 121).

Hasil ciptaan hak cipta sebagai suatu hak milik perorangan yang tidak berwujud, menjadikan pemiliknya dapat melaksanakan haknya dengan batas - batas tertentu, dan mengecualikan pihak lain untuk menikmati, kecuali dengan izin pemilik (Djoko Hadi Santoso, Agung Sujatmiko, 2017: 199).

Apabila orang lain ingin mengakui hak cipta tersebut maka harus dengan seizin penciptanya atau pemegang hak cipta. Hal ini dikarenakan bahwa suatu ciptaan itu 
tidak mudah diciptakan, butuh proses yang lama, dimulai dari gagasan inspirasi sang pencipta kemudian di tuangkan dalam pemikiran yang melahirkan suatu ciptaan (Dendi Martha R, Sentot P.S, M. Zairul Alam, 2015: 10). Pelindungan hukum dalam hak cipta dibedakan menjadi 2 (dua) macam, pelindungan hukum bagi rakyat yaitu pelindungan hukum preventif (mencegah) dan pelindungan hukum yang represif (menekan), pada pelindungan hukum yang preventif, kepada rakyat diberi kesempatan untuk mengajukan keberatan atau pendapatnya sebelum sesuatu keputusan pemerintah mendapat bentuk yang definitif (Zainul Amin, 2018: 131).

Subjek hukum hak cipta adalah pencipta yaitu seorang atau beberapa orang yang secara sendiri-sendiri atau bersama-sama menghasilkan suatu ciptaan yang bersifat khas dan pribadi (Sudjana, 2019:74). Ide dasar pelindungan hak cipta mempunyai tiga syarat substantif yang meliputi tiga elemen, yaitu originalitas, kreativitas, serta fiksasi (Muhammad Fahmi Rois, Kholis Roisah, 2018: 408).
Sifat dasar yang melekat pada hak cipta (the nature of copyright) (Achmad Chosyali, 2018: 51), yaitu:

a) Hak cipta adalah hak milik (property right);

b) Hak cipta adalah hak yang terbatas waktunya (limited duration);

c) Hak cipta adalah sebuah hak yang bersifat eksklusif (exclusive right); dan

d) Hak cipta adalah sebuah kumpulan hak didalam sebuah karya (a multiple right, a bundle of right in one work).

Logo/lukisan yang dilindungi oleh rezim hak merek adalah berfungsi sebagai pembeda yang membedakan antara satu produk barang atau jasa dengan produk barang atau jasa lainnya. Berdasarkan pengamatan penelitian ini, di Indonesia dengan kepadatan jumlah penduduk yang sangat tinggi dan dengan dibanjirinya oleh berbagai macam produk atau jasa, produsen dituntut untuk semakin kreatif dalam hal menarik perhatian konsumen.

Pemilihan merek tertentu bukanlah hal mudah dalam dunia bisnis karena merek harus menarik, 
mudah diingat dan memiliki karakteristik khusus sehingga konsumen tertarik untuk membeli barang atau menggunakan jasanya (Laina Rafianti, 2013: 2).

Saat ini, banyak produsen yang mulai untuk menggunakan logo/lukisan merek sebagai sarana periklananan atas produk-produk atau jasa-jasa mereka. Sedangkan lukisan yang dilindungi oleh rezim hak cipta merupakan hasil karya dari seni rupa, tentunya hal tersebut sangat berbeda dilihat dari segi perspektif tujuan pelindungan dari kedua kekayaan intelektual tersebut.

Namun, kecenderungan yang terjadi dalam praktik adalah adanya kesalahpahaman dalam mengartikan kedua bentuk konsep pelindungan tersebut di dalam masyarakat. Dan, juga adanya tumpang tindih pengaturan terkait logo/lukisan dalam masing-masing rezim pelindungan kekayaan intelektual tersebut yang dapat menimbulkan terjadinya pelanggaran kekayaan intelektual di kemudian hari.

Thailand adalah salah satu negara Asia yang menjadi anggota konvensi atau perjanjian internasional atau perjanjian yang berkaitan dengan masalah kekayaan intelektual seperti Konvensi Paris untuk Pelindungan Kekayaan Industri, Perjanjian Kerjasama Paten atau Perjanjian tentang Aspek Terkait Perdagangan Hak Kekayaan Intelektual (Vannasaeng dan Tankarnjananurak). Untuk memenuhi kewajibannya, Thailand telah mengambil tindakan positif untuk memberlakukan undangundang untuk mematuhi instrumen internasional tersebut. Hingga saat ini, Thailand memberlakukan peraturan perundang-undangan terkait merek dan hak cipta yaitu (Fougere, 2013: 10): merek (UndangUndang Merek (Thailand Trademark Act) (1991) sebagaimana diubah Nomor 2 Tahun 1999 dan kemudian diubah kembali Nomor 3 Tahun 2016, hak cipta (Undang-Undang Hak Cipta (Thailand Copyright Act) (1994) sebagaimana diubah Nomor 2 Tahun 2015 dan kemudian diubah Nomor 4 Tahun 2018).

Dalam penelitian ini, dirincikan persamaan dan perbedaan sistem pengaturan logo sebagai suatu kekayaan intelektual menurut perspektif hukum merek dan hak cipta di Thailand: 
Tabel 2

Perbandingan Konsep Kepemilikan Merek \& Hak Cipta di Indonesia dan

Thailand

\begin{tabular}{|c|c|c|}
\hline Obyek Perbandingan & Indonesia & Thailand \\
\hline $\begin{array}{l}\text { Konsep Kepemilikan } \\
\text { Merek }\end{array}$ & Sistem First-to-file & Sistem First-to-file (ASEAN Briefing, 2016) \\
\hline $\begin{array}{l}\text { Konsep Kepemilikan } \\
\text { Hak Cipta }\end{array}$ & Prinsip deklaratif & Prinsip deklaratif \\
\hline $\begin{array}{l}\text { Instansi yang } \\
\text { Berwenang terkait } \\
\text { pendaftaran HKI }\end{array}$ & $\begin{array}{l}\text { Direktorat Jenderal Kekayaan } \\
\text { Intelektual, Kemenkumham }\end{array}$ & $\begin{array}{l}\text { Department of Intellectual Property (DIP) yang } \\
\text { telah dibentuk sejak pada tanggal } 3 \text { Mei 1992. DIP } \\
\text { dibawah pengawasan dari Kementerian } \\
\text { Perdagangan. (Vannasaeng dan Tankarnjananura). }\end{array}$ \\
\hline $\begin{array}{l}\text { Dasar Hukum } \\
\text { Pengaturan Merek }\end{array}$ & $\begin{array}{l}\text { Undang-Undang Nomor } 20 \\
\text { Tahun } 2016 \text { tentang Merek dan } \\
\text { Indikasi Geografis }\end{array}$ & $\begin{array}{l}\text { Undang-Undang Merek (Thailand Trademark Act) } \\
\text { (1991) sebagaimana diubah Nomor } 2 \text { Tahun } 1999 \\
\text { dan kemudian diubah kembali Nomor } 3 \text { Tahun } \\
2016\end{array}$ \\
\hline $\begin{array}{l}\text { Dasar Hukum } \\
\text { Pengaturan Hak Cipta }\end{array}$ & $\begin{array}{l}\text { Undang-Undang Nomor } 28 \\
\text { Tahun } 2014 \text { tentang Hak Cipta }\end{array}$ & $\begin{array}{l}\text { Undang-Undang Hak Cipta (Thailand Copyright } \\
\text { Act) (1994) sebagaimana diubah Nomor } 2 \text { Tahun } \\
2015 \text { dan kemudian diubah Nomor } 4 \text { Tahun } 2018\end{array}$ \\
\hline $\begin{array}{l}\text { Periode pelindungan } \\
\text { merek }\end{array}$ & $\begin{array}{c}10 \text { tahun dan dapat } \\
\text { diperpanjang (Pasal } 35 \\
\text { UUMIG) }\end{array}$ & $\begin{array}{c}10 \text { tahun dan dapat diperpanjang (Pasal 53, UUM } \\
\text { Thailand) }\end{array}$ \\
\hline $\begin{array}{l}\text { Periode pelindungan } \\
\text { hak cipta }\end{array}$ & $\begin{array}{l}\text { Berlaku selama selama hidup } \\
\text { Pencipta dan terus berlangsung } \\
\text { selama } 70 \text { (tujuh puluh) tahun } \\
\text { setelah Pencipta meninggal } \\
\text { dunia, terhitung mulai tanggal } \\
1 \text { Januari tahun berikutnya. } \\
\text { (Pasal 58, UUHC Indonesia) }\end{array}$ & $\begin{array}{l}\text { Suatu ciptaan memiliki masa berlaku seumur hidup } \\
\text { pencipta dan } 50 \text { tahun setelah kematiannya (Pasal } \\
19 \text { UUHC Thailand) }\end{array}$ \\
\hline Tipe merek & $\begin{array}{l}6 \text { tipe merek: merek kata, } \\
\text { merek kata dan lukisan, merek } \\
\text { lukisan, merek 3D, merek } \\
\text { suara, merek hologram }\end{array}$ & $\begin{array}{l}3 \text { tipe merek: merek kata: yang terdiri dari satu kata } \\
\text { atau lebih, merek lukisan: gambar (figures), } \\
\text { lukisan (drawings) atau logo, merek kombinasi: } \\
\text { kombinasi antara kata dan lukisan (logo) } \\
\text { (www.smartlegalth.com). }\end{array}$ \\
\hline
\end{tabular}


Di Thailand, menurut ketentuan perundang-undangan merek yang berlaku pengertian merek adalah suatu foto, gambar, perangkat yang diciptakan, logo, nama, kata, frasa, huruf, angka, tanda tangan, kombinasi warna, elemen figuratif, suara atau kombinasi keduanya. Sedangkan, merek dagang adalah suatu merek yang digunakan atau diusulkan untuk digunakan pada atau keterkaitan dengan barang-barang untuk membedakan barang-barang tersebut dengan merek dagang yang digunakan oleh pihak lainnya (Undang-Undang Merek di Thailand ((Thailand Trademark Act) Tahun 1991 dan Perubahannya No. 2 Tahun 2000 dan No. 3 Tahun 2016 (2016)).

Sebagai anggota Organisasi Perdagangan Dunia (WTO) dan Organisasi Kekayaan Intelektual Dunia (WIPO), Thailand pada umumnya mematuhi standar kekayaan intelektual internasional yang ditetapkan oleh Perjanjian tentang Aspek Terkait Perdagangan atas Hak Kekayaan Intelektual (TRIPS).

Lain halnya dengan merek, hak cipta di Thailand melindungi karya pencipta dengan memberinya hak eksklusif atas karyanya untuk jangka waktu terbatas dan substansial. Dengan cara ini, penulis dari karya kreatif akan dapat mengontrol penggunaan ekonomis dari karyanya dengan sejumlah cara sehingga ia dapat menerima pembayaran. Hak cipta melindungi "karya asli penulis" pencipta seperti karya sastra, karya dramatis, karya musik, rekaman suara, pantomim dan karya koreografi, karya arsitektur, karya seni visual seperti karya gambar, grafis dan pahatan, gambar bergerak dan audiovisual lainnya karya-karya, karya seni dan karya intelektual lainnya baik yang diterbitkan maupun tidak diterbitkan untuk disalin. Hak cipta melindungi cara di mana fakta atau informasi tersebut diungkapkan, dipilih atau diatur. Pemegang hak cipta memiliki hak eksklusif untuk mengotorisasi atau melarang penggunaan tertentu dari karyanya. Hak cipta mencegah orang lain untuk mengambil keuntungan dari karya kreatif (www.thailandcourt.com).

Undang-Undang Hak Cipta di Thailand pertama kali disahkan pada tahun 1978, kemudian dicabut dan diubah pertama kali pada tanggal 21 Desember 1994 dan baru efektif pada 
tanggal 22 Maret 1995. Lebih lanjut diubah kembali untuk yang kedua kalinya menjadi UUHC Nomor 2 Tahun 2015 dan yang terakhir diubah Kembali sehingga menjadi Nomor 4 Tahun 2018. Dalam Undang-Undang, hak cipta diartikan sebagai hak ekslusif untuk melakukan tindakan apapun berdasarkan Undang-Undang terkait dengan karya yang diciptakan atau dibuat oleh pencipta. Hak ekslusif melingkupi tindakan untuk mereproduksi atau adaptasi; periklanan; menyewakan program komputer asli atau kopi, bahan audiovisual, film sinematografi, dan rekan suara; memberikan keuntungan-keuntungan yang timbul dari hak cipta ke yang lainnya; dan mengizinkan pihak lain untuk menggunakan hak-hak tersebut.

Hak cipta di Thailand melindungi karya-karya dalam kategori-kategori karya sastra yang melingkupi: program komputer, karya dramatik, karya artistik, karya musik, bahan audiovisual, karya sinematografi, bahan-bahan rekaman, suara yang disebarluaskan atau gambar-gambar yang disebarluaskan, atau karyakarya lainnya dalam bidang literatur, ilmu pengetahuan atau seni rupa.
Pelindungan hak cipta melingkupi ekspresi-ekspresi orisinal dari ide-ide dimana penulis membuat atau menciptakan ekspresi-ekspresi tersebut, namun tidak mencakup ide, langkah, proses, sistem, cara penggunaan, konsep, prinsip, dan teori ilmu pengetahuan atau matematika oleh penulis dalam pembuatan karya mereka. Ekspresi dari ide dapat berupa metode atau bentuk apapun (International Legal Counsellors Thailand Limited, 2017: 194-195).

Karya hak cipta tidak memerlukan kekhasan yang diperlukan untuk permohonan merek, tetapi harus merupakan ekspresi kreatif dari ide orisinal dari para pembuatnya. Tingkat orisinalitas atau kreativitas yang diperlukan minimal (International Legal Counsellors Thailand Limited, 2017: 194-195).

Hak cipta timbul dalam karya hak cipta pada saat penciptaannya. Registrasi tidak diperlukan. Tetapi dimungkinkan dan opsional untuk mencatatkan karya hak ciptanya ke Kantor Hak Cipta dari Departemen Kekayaan Intelektual (“DIP”). Pencatatan hak cipta pada DIP bukan merupakan prasyarat untuk 
pelindungan dan penegakannya. Namun, pencatatan hak cipta disarankan karena sertifikat pencatatan hak cipta merupakan dokumen bukti penting tentang kepemilikan karya (International Legal Counsellors Thailand Limited, 2017: 194-195).

Merek dan hak cipta, walaupun berbeda dan terpisah, dapat terjadi tumpang tindih. Hak cipta melindungi karya-karya kreatif seperti gambar, tulisan, seni visual, rekaman musik dan audio. Merek, di sisi lain, melindungi frasa, kata, dan simbol yang digunakan untuk mengidentifikasi suatu produk dan menandakan asalnya (International Legal Counsellors Thailand Limited, 2017: 194-195).

Di Thailand, Undang-Undang Hak Cipta (Copyright Act) dan Undang-Undang Merek (Trademark Act) tidak memiliki ketentuan tentang tumpang tindih merek dan hak cipta. Namun, Undang-Undang Hak Cipta dan Undang-Undang Merek tidak mengecualikan pelindungan dari karya artistik yang juga dapat dilindungi atau digunakan sebagai merek. Karya hak cipta dalam kategori karya artistik dapat didaftarkan sebagai merek logo dan digunakan jika memenuhi persyaratan hukum untuk merek di bawah Undang-Undang Merek (Somwaiya dan Kerativitayana, 2019).

Berikut adalah beberapa merek lukisan/logo yang juga dilindungi sebagai karya hak cipta dalam kategori karya artistik di bawah Undang-Undang Hak Cipta di Thailand:

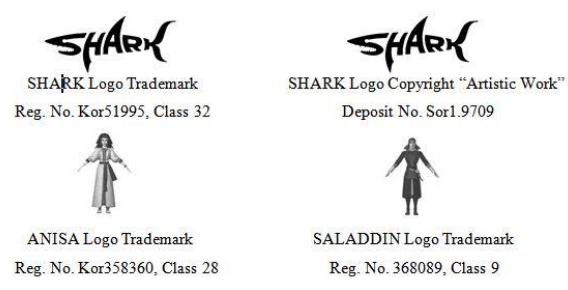

Pada praktiknya, sebagian besar karakter terkenal dari film dan buku komik sudah dilindungi sebagai karya hak cipta di bawah Undang-Undang Hak Cipta yang juga terdaftar sebagai merek untuk barang-barang seperti mainan, cangkir, t-shirt, topi, tas tangan, dan lain-lain. Namun, perlu dicatat bahwa pengadilan Thailand kadang-kadang tidak mengakui merek sebagai hak cipta dan sebaliknya karena pengadilan menerapkan gagasan bahwa subyek yang berhak atas pelindungan berdasarkan 
beberapa undang-undang tidak boleh diberikan pelindungan yang tumpang tindih (Putusan Mahkamah Agung No. 15082 / 2556 (AD 2013)) (Somwaiya dan Kerativitayana, 2019).

Penegakan merek logo yang diajukan ke pengadilan hanya di bawah Undang-Undang Merek saja atau di bawah Undang-Undang Merek dan Undang-Undang Hak Cipta atau hukum lain yang berlaku. Klaim untuk penegakan merek logo dan hak ciptanya (dalam hal ini juga memenuhi syarat sebagai karya hak cipta) dapat diajukan di satu pengadilan yang diproses berdasarkan Undang-Undang Merek dan UndangUndang Hak Cipta (Somwaiya dan Kerativitayana, 2019).

Di Thailand, penegakan merek logo secara hukum dapat membawa perkara tersebut ke pengadilan di bawah Undang-Undang Merek sendiri atau di bawah UndangUndang Merek dan Undang-Undang Hak Cipta atau hukum lain yang berlaku. Meskipun pengadilan Thailand biasanya merasa lebih bijaksana untuk menerapkan gagasan hukum bahwa undang-undang yang memberikan pelindungan pada suatu pokok masalah tidak boleh tumpang tindih, jika pihak ketiga menggunakan karya hak cipta orang lain sebagai mereknya sendiri atau sebaliknya atau bebas membonceng hak orang lain, pengadilan dapat memberikan pelindungan di bawah UndangUndang Merek dan Undang-Undang Hak Cipta kepada penulis asli/pemilik karya dan memerintahkan kepada pihak yang beriktikad buruk atau pembonceng bebas (free rider) tersebut karena bertentangan dengan kebijakan publik dan moral orang Thailand yang baik (Somwaiya dan Kerativitayana, 2019).

Di Indonesia, suatu ciptaan yang dilindungi oleh hak cipta adalah setiap hasil karya cipta di bidang ilmu pengetahuan, seni, dan sastra yang dihasilkan atas inspirasi, kemampuan, pikiran, imajinasi, kecekatan, keterampilan, atau keahlian yang diekspresikan dalam bentuk nyata yang terdiri atas: (a) buku, pamflet, perwajahan karya tulis yang diterbitkan, dan semua hasil karya tulis lainnya; (b) ceramah, kuliah, pidato, dan Ciptaan sejenis lainnya; (c) alat peraga yang dibuat untuk kepentingan pendidikan dan ilmu pengetahuan; (d) lagu dan/atau musik 
dengan atau tanpa teks; (e) drama, drama musikal, tari, koreografi, pewayangan, dan pantomim; (f) karya seni rupa dalam segala bentuk seperti lukisan, gambar, ukiran, kaligrafi, seni pahat, patung, atau kolase; (g) karya seni terapan; (h) karya arsitektur; (i) peta; (j) karya seni batik atau seni motif lain; (k) karya fotografi; (l) Potret; (m) karya sinematografi; (n) terjemahan, tafsir, saduran, bunga rampai, basis data, adaptasi, aransemen, modifikasi dan karya lain dari hasil transformasi; (o) terjemahan, adaptasi, aransemen, transformasi, atau modifikasi ekspresi budaya tradisional; (p) kompilasi Ciptaan atau data, baik dalam format yang dapat dibaca dengan Program Komputer maupun media lainnya; (q) kompilasi ekspresi budaya tradisional selama kompilasi tersebut merupakan karya yang asli; (r) permainan video; dan (s) Program Komputer (Pasal 40 UUHC No. 28 Tahun 2014).

Sedangkan di Thailand, suatu ciptaan yang dilindungi oleh hak cipta adalah karya sastra, program komputer, karya dramatik, karya artistik, karya musik, karya audiovisual, karya sinematografi, perekaman suara, penyiaran, reproduksi, adaptasi (Pasal 4 UUHC Thailand Tahun 1994, dan Perubahannya No. 2 Tahun 2015 dan No. 4 Tahun 2018).

Pelindungan hak cipta hanya diterapkan dalam kaitannya dengan komersialisasi ciptaannya (the works). Dengan demikian, yang menjadi obyek adalah ciptaan (works) itu sendiri yang dikomersialkan melalui perbanyakan atau pengumuman, bukan produk yang ada di dalam kemasan atau barang-barang (produk) yang dibuat berdasarkan pola desain tertentu (Prawiranegara dan Sardjono, 2014: 2).

Kemasan biasanya digunakan sebagai penanda (merek) dari produk yang dikemas. Dengan demikian, komersialisasinya dilakukan bukan terhadap kemasannya, melainkan atas produknya. Contoh: produknya adalah kacang. Kacang itu dikemas di dalam plastik, karton, atau kertas yang diberi gambar dan tanda-tanda lainnya. Meskipun gambar pada kemasan tentu saja diciptakan oleh seseorang, tetapi gambar itu sendiri tidak dimaksudkan sebagai produknya, melainkan sebagai identitas produk atau untuk mengidentifikasi suatu produk dari 
produk lainnya yang sejenis. Itu sebabnya dipersyaratkan adanya daya pembeda (distinctiveness). Di sinilah domain hukum merek (Prawiranegara dan Sardjono, 2014: 6).

Jadi, pelindungan hak cipta hanya diterapkan dalam kaitannya dengan komersialisasi Ciptaan. Dengan demikian yang menjadi objek adalah Ciptaan itu sendiri yang dikomersialkan melalui perbanyakan atau pengumuman (Prawiranegara dan Sardjono, 2014: 6).

Ciptaan (works) yang dimaksud dalam konteks pelindungan hak cipta adalah ciptaan dalam lapangan ilmu pengetahuan, seni, atau sastra. WIPO IP Handbook dengan jelas menyebutkan bahwa "Copyright protection is above all one of the means of promoting, enriching, and disseminating the national cultural heritage". Dengan demikian, ada kualitas tertentu dari ciptaan (bersifat kultural), yang tentunya tidak dimaksudkan sebagai tanda merek (mark), dan bukan pula sebagai pola (pattern). Ciptaan dibuat dalam kaitannya dengan ilmu pengetahuan (misal: text book), seni (musik, lukisan, atau patung), atau sastra (puisi, novel, dan sebagainya)
(Prawiranegara dan Sardjono, 2014: 18).

Penelitian ini berkesimpulan bahwasanya logo atau lukisan yang dilingkupi dalam pelindungan hak cipta dan hak merek adalah 2 (dua) hal yang berbeda karena logo atau lukisan yang dilindungi oleh rezim hak cipta adalah masuk ke dalam karya seni rupa sehingga logo/lukisan tersebut merupakan suatu hasil dari karya seni yang diekspresikan dalam bentuk nyata. Sedangkan, logo atau lukisan yang dilingkupi dalam pelindungan hak merek adalah berasal dari salah satu bentuk tanda yang digunakan dalam kegiatan perdagangan barang atau jasa untuk membedakan produk atau jasa satu dengan lainnya berdasarkan klasifikasi yang dikelompokkan ke dalam kelas-kelas barang dan/atau jasa.

Sistem klasifikasi merek yang paling banyak digunakan adalah sistem klasifikasi merek internasional (yang disebut dengan sistem Nice Classification untuk klasifikasi merek) yang memiliki 34 kelas barang dan 11 untuk kelas jasa (www.wipo.int).

Indonesia bukan merupakan Negara yang meratifikasi Nice 
Agreement, tapi termasuk sebagai Negara pengguna Klasifikasi Nice dalam rangka harmonisasi sistem pendaftaran merek internasional. Klasifikasi Nice tidak memberikan efek hukum terhadap pelindungan merek di Negara yang bersangkutan. Klasifikasi hanya sebagai alat administrasi sistem pendaftaran merek (Utami, 2014). Pada praktiknya, saat ini sistem klasifikasi Nice yang digunakan di Indonesia adalah mengacu kepada Nice Agreement 11th (11th edition) di Indonesia.

Kunci untuk menciptakan merek, berdasarkan definisi American Marketing Assosiation (AMA) adalah kemampuan produsen memilih elemen-elemen merek, agar konsumen dapat mengidentifikasi produk dan membedakan dari produsen lain. Elemen-elemen merek adalah komponen-komponen yang berbeda dari merek, yang mengidentifikasi dan membedakannya dari produsen lain, yaitu: nama, logo, simbol, desain kemasan, dan karakteristikkarakteristik lainnya. Tidak hanya nama merek, elemen merek lainnya seperti logo dan simbol juga dapat didasarkan pada nama orang, tempat, benda, dan image yang abstrak (Sekar Sari, 2017: 195).

Maka dapat disimpulkan secara jelas bahwasanya logo/lukisan yang dilindungi oleh rezim hak merek adalah berfungsi sebagai pembeda yang membedakan antara satu produk barang atau jasa dengan produk barang atau jasa lainnya. Mengingat pada saat ini, berdasarkan pengamatan dari penelitian ini di Indonesia dengan kepadatan jumlah penduduk yang sangat tinggi dan dengan dibanjirinya oleh berbagai macam produk atau jasa, produsen dituntut untuk semakin kreatif dalam hal menarik perhatian konsumen. Sehingga banyak produsen yang mulai untuk menggunakan logo/lukisan merek sebagai sarana periklanan atas produk-produk mereka. Sedangkan lukisan yang dilindungi oleh rezim hak cipta merupakan hasil karya dari seni rupa, tentunya hal tersebut sangat berbeda dilihat dari segi perspektif tujuan pelindungan dari kedua kekayaan intelektual tersebut.

Namun, kecenderungan yang terjadi dalam praktik adalah adanya kesalahpahaman dalam mengartikan 
kedua bentuk pelindungan tersebut di dalam masyarakat yang akan menimbulkan pelanggaran kekayaan intelektual di kemudian hari. Sebagai contoh misalnya, kasus sengketa logo hak merek terhadap lukisan yang telah dicatatkan pada Kantor Ditjen KI yakni logo merek "PSMS + LOGO". Dalam kasus sengketa ini, yang bertindak sebagai Penggugat adalah DR. H. MAHYONO, SPB, SPBA dan pihak Tergugat I adalah PT. PESEMES MEDAN, Turut Tergugat II adalah SYUKRI WARDI (Direktur Utama PT. PESEMES), Turut Tergugat III adalah Ditjen Kekayaan Intelektual atas obyek sengketa gugatan pembatalan atas Ciptaan No. 067984 tanggal 28

Maret 2014 berikut Perbaikan Surat Pendaftaran Ciptaan No.: HKI.2HI.01.07-29 tanggal 28 Mei 2014 yang diterbitkan Kementerian Hukum dan HAM RI Dirjen Hak Kekayaan Intelektual (www.sipp.pnmedankota).

Penggugat dalam masa persidangan bertindak sebagai Ketua Umum PSMS Medan (Rio, http://innews.co.id/logo-psmsmedan-.). Penggugat berkeberatan atas dicatatkannya Ciptaan lukisan
PSMS Medan 1950 oleh karena diduga lukisan tersebut didaftarkan sebagai hak cipta atas iktikad tidak baik karena meniru dan mendompleng keterkenalan dari merek yang menggunakan logo (pdkiindonesia.dgip.go.id ) atau lukisan yang sama seperti lukisan Tergugat I dan II sebagai berikut:

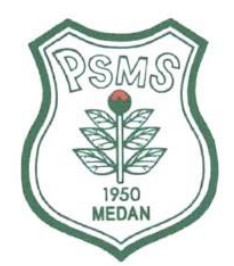

Penamaan merek dan lukisan "PSMS" telah didaftarkan oleh Penggugat yang bertindak sebagai Ketua Umum PSMS Medan pada saat pengajuan permohonan pendaftaran merek pada tanggal 28 Februari 2014 dengan Nomor Agenda Permohonan J002014008760 yang mencakup kelas jasa: Klub sepak bola, sekolah bola. Permohonan pendaftaran merek telah disetujui dengan diterbitkannya sertifikat merek dengan Nomor Daftar IDM000588696 pada tanggal 7 Desember 2017. Periode pelindungan merek tersebut akan berakhir pada tanggal 28 Februari 2024 (pdkiindonesia.dgip.go.id). 
Oleh Penggugat, merek tersebut diajukan ke dalam beberapa kelas yakni kelas 16 yang meliputi tiket, alat tulis kantor, buku, majalah, tabloid, surat kabar, pulpen, pensil, kertas, stiker; kelas 25 yang meliputi pakaian, baju, celana, jersey, t-shirt, baju olahraga, celana olahraga, jaket, training, syal, alas kaki, sepatu, sendal, kaos kaki, tutup kepala, topi (pdki-indonesia.dgip.go.id). Sesuai dengan fungsinya, logo merek "PSMS" yang terdiri atas 6 helai tembakau berwarna hijau dengan bunga warna putih digunakan sebagai alat pembeda antara produk-produk alat tulis kantor, pakaian satu dengan yang lainnya.

Dalam tuntutannya, menurut Penggugat PSMS berdiri sejak tahun 1950, karena Sumut ini terdiri dari beberapa etnis, pada saat itu PSMS terdiri dari enam klub, enam klub ini terdiri dari beberapa etnik yaitu Indian Football Team (IFT), PS Alwhatan (etnik Arab), PS Sahata (Etnik Batak), PS Medan Sport (Medan Putra-etnik Melayu), PS PTP (Deli Maskapai) dan PS Persatuan Olahraga Polisi (POP) Polisi. Lahirnya logo PSMS Medan 1950 dengan logo tembakau karena Sumut dikenal sebagai penghasil tembakau Deli terbesar. Sumut terkenal dengan tembakau Deli. Jadi logo PSMS dibuat berbentuk daun tembakau dan karena PSMS pada saat itu terdiri dari enam klub maka dibuatlah daun itu enam lembar. Penggugat sudah bermain sejak generasi kedua yang saat ini tertua di PSMS tidak mengenal siapa itu Syukri Wardi (Turut Tergugat II) yang mengklaim logo tersebut miliknya. Sementara, Parlin Siagian (saksi) menjelaskan dalam keterangannya bahwa dirinya bermain pada tahun 1971 dan sudah menggunakan logo tembakau tersebut di dadanya. Menurut Parlin Siagian "saya bermain tahun 1971 dan disitu sudah digunakan logo tembakau ini di dalam kustom". "Logo itu setahu saya sudah dibuat pada tahun 1950”. "Kalau yang saya dengar yang buat Pak Maja Purba Walikota, bukan Syukri Wardi bukan dia pencipta". Bahkan Parlin Siagian menjelaskan bahwa logo tersebut sudah pernah dipakainya dalam pertandingan internasional. Waktu main di Singapura, Vietnam, Birma, Malaysia, Thailand dan negara lainnya logo ini sudah dipakai dulu. 
Jadi ini sudah resmi milik PSMS dan warga Sumut bukan milik perorangan (Hutauruk,

www.medan.tribunnews.com).

Penggugat berpendapat bahwasanya hasil sidang adalah kemenangan bersama bukan pribadinya. Penggugat mewakili PSMS sebagai ketua umum memenangkan gugatan atas kepemilikan logo PSMS yang selama ini diakui kepemilikannya oleh salah satu teman kita. Tujuan pengajuan gugatan ini semata-mata bahwa PSMS bukan milik pribadi tapi bersama (Nina, www.pojoksatu.id).

Pada akhirnya Pengadilan Negeri Medan memutuskan pada tanggal 17 Desember 2019 (informasi detail perkara Pengadilan Niaga Medan) bahwasanya dalam pokok perkara:

a) Mengabulkan gugatan Penggugat untuk seluruhnya;

b) Menyatakan Penggugat adalah pihak yang berhak untuk mengajukan gugatan pembatalan pencatatan Ciptaan Surat Pendaftaran Ciptaan No.: 067984 Tanggal 28 Maret 2014 berikut Perbaikan Surat Pendaftaran Ciptaan No.: HKI.2-HI.01.07-29 tanggal 28 Mei 2014 yang diterbitkan Kementerian Hukum dan HAM RI Dirjen Hak Kekayaan Intelektual (Turut Tergugat);

c) Menyatakan Logo "PSMS Medan 1950" adalah merek terkenal milik PSMS Medan yang sudah dikenal sejak tahun 1950

d) Menyatakan Tergugat I dan Tergugat II adalah Pemohon yang beriktikad tidak baik;

e) Menyatakan batal pencatatan ciptaan Surat Pendaftaran Ciptaan No.: 067984 Tanggal 28 Maret 2014 berikut Perbaikan Surat Pendaftaran Ciptaan No.: HKI.2-HI.01.07-29 tanggal 28 Mei 2014 yang diterbitkan Kementerian Hukum dan HAM RI Dirjen Hak Kekayaan Intelektual (Turut Tergugat);

f) Memerintahkan Kementerian Hukum dan HAM RI Dirjen Hak Kekayaan Intelektual (Turut Tergugat) untuk mencatat pembatalannya dalam daftar umum ciptaan;

g) Menghukum Tergugat I dan Tergugat II untuk membayar biaya yang timbul dalam perkara ini sejumlah $\mathrm{Rp}$. 


$$
\begin{aligned}
& 1.966 .000,- \text { (satu juta sembilan } \\
& \text { ratus enam puluh enam ribu } \\
& \text { rupiah). }
\end{aligned}
$$

Berdasarkan teori kepentingan individu, pemilik merek harus dihargai atas segala jerih payahnya yang telah membuat merek, mendaftarkan merek, dan membentuk reputasi (goodwill) bagi merek tersebut, sehingga pemilik merek memiliki kepentingan individu untuk menggunakan hak eksklusifnya dalam kegiatan perdagangan barang dan/atau jasa (Amirulloh dan Kusumawati, 2014: 472).

\section{Pengaturan Kasus Logo "Miffy" Di Thailand Dalam Perspektif Hukum di Indonesia}

Sama halnya dengan Indonesia, di Thailand juga ada kasus yang hampir sama terkait adanya tumpang tindihnya pengaturan logo/lukisan dalam perspektif pelindungan hak atas merek dan hak cipta. Berdasarkan Keputusan Mahkamah Agung No. 4588/2552 (A.D. 2009) terhadap Kasus Sengketa Logo "MIFFY" adalah sebagai berikut (Somwaiya dan Kerativitayana):

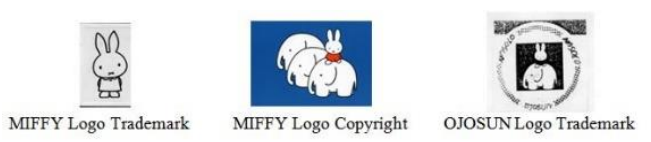

Tergugat mengambil karakter fiksi kelinci dari merek logo Penggugat "MIFFY" dan menggunakannya sebagai salah satu elemen dalam merek logo OJOSUN milik Tergugat. Tergugat juga mengajukan permohonan pendaftaran merek tersebut ke Kantor Merek (“DIP”). Penggugat mengajukan oposisi kepada Kantor Merek terhadap permohonan pendaftaran merek Tergugat tersebut tetapi oposisi gagal. Penggugat kemudian mengajukan banding ke Dewan Merek ("TradeMark Board"). Dan, Dewan Merek memutuskan bahwa merek Tergugat tidak secara membingungkan mirip dengan merek Penggugat. Penggugat kemudian mengajukan gugatan berdasarkan pelanggaran hak cipta terhadap logo "MIFFY" (sebagai karya artistik). Penggugat juga mengklaim bahwa merek Tergugat secara membingungkan mirip dengan merek Penggugat. Mahkamah Agung memutuskan bahwa, meskipun secara keseluruhan merek dagang Tergugat tidak secara membingungkan mirip 
dengan merek $\log 0$ "MIFFY" Penggugat, namun merek dagang Tergugat mengandung reproduksi karya artistik hak cipta dari Penggugat. Pengadilan beralasan bahwa tujuan pengaturan perundangundangan dalam Kantor Merek adalah untuk melindungi orang yang bertindak dengan iktikad baik dan, oleh karena itu, mereproduksi atau memodifikasi karya hak cipta orang lain dengan itikad tidak baik dan menggunakan karya hak cipta yang direproduksi atau dimodifikasi sebagai merek bertentangan dengan tujuan pembentukan dan pengaturan perundang-undangan Merek. Pengadilan berkesimpulan bahwa merek dagang Tergugat tidak dapat didaftar karena bertentangan dengan kebijakan publik dan moral orang Thailand yang baik (Somwaiya dan Kerativitayana).

Di Thailand, UUM maupun UUHC tidak secara tegas menangani masalah ini. Namun demikian, UUHC tidak mengecualikan pelindungan dari suatu karya artistik yang juga dapat dilindungi atau digunakan sebagai merek dan UUM juga tidak melarang karya artistik untuk didaftarkan sebagai merek. Karya hak cipta dalam kategori karya artistik dapat didaftarkan sebagai merek logo dan digunakan jika memenuhi persyaratan hukum untuk merek di bawah ketentuan UUM. Dengan cara yang sama, karya artistik dalam merek logo juga dapat dilindungi sebagai karya hak cipta jika memenuhi persyaratan hukum berdasarkan Undang-Undang Hak Cipta.

Penegakan merek logo secara hukum dapat diajukan ke pengadilan di bawah Undang-Undang Merek sendiri atau di bawah UndangUndang Merek dan Undang-Undang Hak Cipta. Namun, perlu dicatat bahwa pengadilan di Thailand kadang-kadang tidak mengakui merek sebagai hak cipta dan sebaliknya karena pengadilan menerapkan gagasan bahwa subyek yang berhak atas pelindungan berdasarkan beberapa undang-undang tidak boleh diberi pelindungan yang tumpang tindih (Somwaiya dan Kerativitayana).

Dalam perspektif hukum merek dan hak cipta di Indonesia, menurut penelitian ini pengaturan pemeriksaan substansi merek yang merupakan suatu persyaratan pemberian keputusan didaftar oleh Direktorat 
Jenderal Kekayaan Intelektual terhadap suatu permohonan pendaftaran merek yang diajukan belum mengakomodasi adanya pemeriksaan secara silang antara obyek kekayaan intelektual lainnya. Khususnya pengaturan dalam hukum merek dan hak cipta yang masingmasing mengakomodasi adanya pelindungan terhadap logo atau lukisan. Dalam Undang-Undang Omnibus Nomor 11 Tahun 2020 tentang Cipta Kerja, yang juga mengatur beberapa aturan terkait paten dan merek pun belum mengatur terkait dengan hal fundamental ini. Di dalam Undang-Undang ini, ditambahkan bahwasanya suatu merek tidak dapat didaftar jika merek mengandung bentuk yang bersifat fungsional. Berikut adalah analogi yang dapat diuraikan:

Penamaan merek "OJOSUN" terdiri dari penamaan kata "OJOSUN" dan lukisan dengan karakter fiksi kelinci.

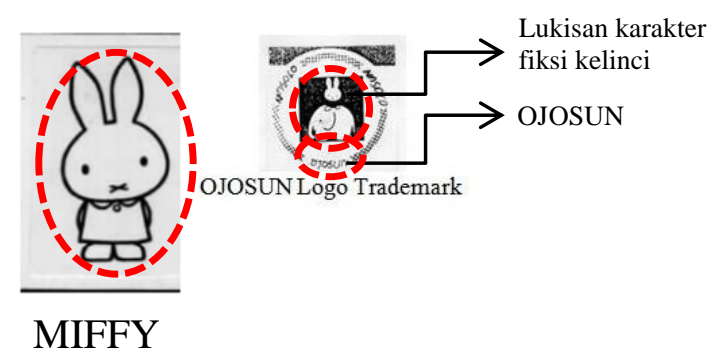

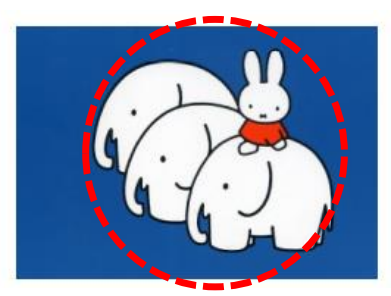

Hak Cipta MIFFY

Diatur di dalam Peraturan Pemerintah Tentang Merek bahwasanya "Penilaian persamaan pada pokoknya dilakukan dengan memperhatikan kemiripan yang disebabkan oleh adanya unsur yang dominan antara Merek yang satu dengan Merek yang lain sehingga menimbulkan kesan adanya persamaan, baik mengenai bentuk, cara penempatan, cara penulisan atau kombinasi antara unsur, maupun persamaan bunyi ucapan, yang terdapat dalam Merek tersebut" (Peraturan Pemerintah Nomor 67 Tahun 2016).

Penelitian ini berpendapat bahwa unsur dominan dari merek "OJOSUN" tersebut adalah terletak pada lukisan dengan karakter fiksi kelinci tersebut. Oleh karenanya, sudah sepatutnya pada saat pemeriksaan substansi permohonan merek tersebut tidak dapat didaftar karena diduga didaftarkan atas dasar 
iktikad tidak baik oleh Pemohon. Sebagaimana telah diatur dalam Pasal 65, Undang-Undang Nomor 28 Tahun 2014 tentang Hak Cipta bahwasanya Pencatatan Ciptaan tidak dapat dilakukan terhadap seni lukis yang berupa logo atau tanda pembeda yang digunakan sebagai merek dalam perdagangan barang/jasa atau digunakan sebagai lambang organisasi, badan usaha, atau badan hukum. Namun, pengaturan yang sama tidak diatur di dalam rezim hukum merek yakni suatu permohonan pendaftaran merek tidak dapat didaftar terhadap logo yang telah dicatatkan dalam pelindungan rezim hukum hak cipta oleh pihak lain. Sehingga, secara praktik sepanjang penamaan merek tidak memiliki persamaan pada pokoknya baik sebagian ataupun seluruhnya dengan merek yang sudah diajukan terlebih dahulu untuk kelas barang dan/atau jasa tidak sejenis ataupun sejenis maka Direktorat Jenderal Kekayaan Intelektual akan memberikan keputusan dapat didaftar meskipun di dalam merek tersebut mengandung logo berupa lukisan dari obyek hak cipta.
Dalam konteks hukum merek, iktikad tidak baik dapat berupa tindakan memalsu merek, meniru, menjiplak, atau menterjemahkan merek berbahasa asing. Tujuannya adalah mudah dibaca, yaitu mendompleng popularitas, menyesatkan kualitas dan mengelirukan sumber asal barang. Sasaran utamanya lebih mengarah pada merek-merek terkenal atau merek yang memiliki pangsa pasar yang besar (Soelistyo, 2017: 10).

Meskipun pelindungan hak cipta dan merek berbeda dalam ruang lingkup dan mengikuti aturan yang berbeda, dasar normatif di antara keduanya memungkinkan tumpang tindih dalam aspek orisinalitas (sine qua non untuk pelindungan hak cipta) dan kekhasan (sine qua non untuk pelindungan merek, bersama dengan prioritas) (Calboli, 2014).

Undang-Undang Hak Cipta dan Merek seharusnya menjalankan tujuan yang berbeda dan melindungi hal-hal yang berbeda: undang-undang hak cipta melindungi karya kepenulisan sementara undangundang merek melindungi tandatanda khas yang digunakan dalam proses perdagangan untuk memberi 
sinyal asal barang komersial. Karena tujuan keduanya yang berbeda, undang-undang hak cipta dan merek dagang memiliki asal yang berbeda dan mengikuti aturan yang berbeda tentang kepemilikan, persyaratan formalitas, durasi, dan pelanggaran. Namun, pelindungan hak cipta dan merek dimungkinkan tumpang tindih. Wilayah dimana kontur tradisional hukum hak cipta dan merek mungkin tumpang tindih, secara umum tetapi tidak secara eksklusif, pelindungan logo dan tanda artistik lainnya atau lambang yang digunakan dalam proses perdagangan; pelindungan slogan dan kalimat pendek juga digunakan dalam perdagangan; pelindungan karakter fiksi yang digunakan sebagai indikator asal komersial, sponsor, atau afiliasi; pelindungan fitur estetika atau artistik dari objek desain industri atau mode; dan sebagainya (Calboli, www.law.scu.edu).

Saat ini ada tiga jenis tumpang tindih: dalam kaitannya dengan konten, kejadian waktu, dan tingkatan geografis. Apa yang disebut dengan "konten tumpang tindih" atau "tumpang tindih horisontal" mengacu kepada situasi dimana Kekayaan
Intelektual yang berbeda bertumpuk (pile up) atau berlaku untuk materi pokok yang dimaksud. Misalnya, logo dapat dilindungi oleh hukum hak cipta dan merek jika semua kondisi kedua Kekayaan Intelektual tersebut terpenuhi. Demikian pula, program komputer dapat dilindungi oleh undang-undang hak cipta dan paten.

Tumpang tindih dapat timbul sebagai akibat dari dua atau lebih jenis upaya yang berbeda (misalnya, karya seni yang dibuat sejak awal untuk menjadi merek terdaftar) atau sebagai akibat dari dua atau lebih Kekayaan Intelektual yang melindungi satu jenis upaya (misalnya, paten dan hak cipta). Merek utamanya melindungi nama produk dan jasa; hak cipta, karya sastra dan artistik; dan paten, produk dan proses baru (Derclaye, 2017).

Dengan pertimbangan hal-hal tersebut di atas, diperlukan suatu harmonisasi pengaturan logo yang dilindungi dalam rezim hukum merek di Indonesia. Oleh karena, pengaturan logo dalam rezim hukum hak cipta telah jelas diatur dalam Pasal 65 Undang-Undang Hak Cipta Nomor 28 Tahun 2014 bahwasanya suatu pencatatan ciptaan tidak dapat dilakukan terhadap logo atau tanda 
pembeda yang digunakan sebagai merek dalam perdagangan barang/jasa atau digunakan sebagai lambang organisasi, badan usaha, atau badan hukum. Sehingga, apabila ada Pemohon hak cipta yang ingin mengajukan pencatatan ciptaan yakni berupa suatu karya seni logo yang merupakan logo yang digunakan sebagai merek dalam kegiatan perdagangan barang/jasa dari pihak lain maka pencatatan atas hak cipta tidak dapat dilakukan oleh Kantor Ditjen KI. Namun, sebaliknya di dalam rezim hukum merek tidak mengakomodasi pengaturan yang sama sebagaimana diatur dalam rezim hukum hak cipta. Oleh karenanya, pelanggaran penggunaan logo dalam rezim hukum merek sangat dimungkinkan terjadi oleh pihak lain yang mengajukan permohonan logo tersebut dalam pelindungan merek atas karya ciptaan oleh pihak lain.

Kecenderungan secara praktik ditemui banyaknya permasalahan logo yang berujung pada sengketa merek atau hak cipta. Di antaranya, adalah diawali dari banyaknya masyarakat yang pada pokoknya belum memahami secara penuh terkait dengan pelindungan kekayaan intelektual di Indonesia. Sehingga timbul minimnya atau rendahnya penghargaan terhadap karya intelektual seseorang yang telah diciptakan, dibangun, dan dibesarkan tersebut. Dengan mengambil baik sebagian ataupun seluruhnya dari suatu karya kekayaan intelektual tidak dianggap sebagai suatu tindakan pelanggaran terhadap suatu karya intelektual yang sudah mendapatkan pelindungan hukum.

Tabel 3

Pengaturan Logo sebagai suatu Karya Intelektual menurut Hukum Merek dan Hak Cipta

\begin{tabular}{lll}
\hline \multicolumn{1}{c}{ Obyek } & \multicolumn{1}{c}{ Indonesia } & Thailand \\
\hline Pengaturan Logo sebagai suatu & Tanda yang dapat ditampilkan & Fotografi, gambar, logo, nama, \\
karya intelektual menurut hukum & secara grafis berupa gambar, logo, kata, frasa, huruf, angka, tanda \\
merek & nama, kata, huruf, angka, susunan & tangan, atau kombinasi \\
& warna, dalam bentuk 2 (dua) & diantaranya (Pasal 4) \\
& dimensi dan/atau 3 (tiga) dimensi, & \\
\hline
\end{tabular}




\begin{tabular}{|c|c|c|}
\hline & $\begin{array}{l}\text { suara, hologram, atau kombinasi } \\
\text { dari } 2 \text { (dua) atau lebih unsur } \\
\text { tersebut -untuk membedakan } \\
\text { barang dan/atau jasa yang } \\
\text { diproduksi oleh orang atau badan } \\
\text { hukum dalam kegiatan } \\
\text { perdagangan barang dan/ atau jasa } \\
\text { (Pasal 1 ayat 1) }\end{array}$ & \\
\hline $\begin{array}{l}\text { Pengaturan logo sebagai suatu } \\
\text { karya intelektual menurut hukum } \\
\text { hak cipta }\end{array}$ & $\begin{array}{l}\text { Logo dilindungi sebagai karya seni } \\
\text { rupa dalam segala bentuk seperti } \\
\text { lukisan, gambar, ukiran, } \\
\text { kaligrafi, seni pahat, patung, atau } \\
\text { kolase. Yang dimaksud dengan } \\
\text { "gambar" antara lain, motif, } \\
\text { diagram, sketsa, logo, unsur-unsur } \\
\text { warna dan bentuk huruf indah } \\
\text { (Pasal } 40 \text { ayat f beserta } \\
\text { penjelasannya) }\end{array}$ & $\begin{array}{l}\text { Logo dilindungi sebagai "karya } \\
\text { artistik" yang memiliki } \\
\text { cakupan yakni: karya lukisan } \\
\text { dan gambar, yang merupakan } \\
\text { suatu kreasi konfigurasi yang } \\
\text { terdiri dari baik garis, } \\
\text { pencahayaan, warna atau hal } \\
\text { lain atau komposisi dari hal } \\
\text { tersebut pada satu atau } \\
\text { beberapa bahan (Pasal 4) }\end{array}$ \\
\hline $\begin{array}{ll}\text { Dasar Hukum } & \text { Persyaratan } \\
\text { Pendaftaran Merek } & \end{array}$ & $\begin{array}{l}\text { Pasal } 20 \text { dan } 21 \text { UUMIG No. } 20 \\
\text { Tahun } 2016\end{array}$ & $\begin{array}{l}\text { Pasal 6, 7, } 8 \text { UUM Tahun } 1991 \\
\text { sebagaimana diubah Nomor } 2 \\
\text { Tahun } 1999 \text { dan kemudian } \\
\text { diubah Nomor } 3 \text { Tahun } 2016\end{array}$ \\
\hline $\begin{array}{l}\text { Dasar Hukum Persyaratan } \\
\text { Pencatatan Hak Cipta }\end{array}$ & $\begin{array}{l}\text { Pasal } 64 \text { hingga } 68 \text {, UUHC Nomor } \\
28 \text { Tahun } 2014\end{array}$ & $\begin{array}{l}\text { Tidak ada persyaratan } \\
\text { pencatatan yang diberlakukan } \\
\text { dalam undang-undang hak cipta } \\
\text { di Thailand }\end{array}$ \\
\hline $\begin{array}{l}\text { Hak Ekonomi Pemilik atau } \\
\text { Pemegang Hak Cipta }\end{array}$ & $\begin{array}{l}\text { Penerbitan Ciptaan; Penggandaan } \\
\text { Ciptaan dalam segala bentuknya; } \\
\text { penerjemahan } \\
\text { pengadaptasian, } \\
\text { pengaransemenan, } \\
\text { pentransformasian } \\
\begin{array}{l}\text { Pendistribusian Ciptaan atan } \\
\text { salinannya; pertunjukan Ciptaan; } \\
\text { Pengumuman } \\
\text { Komunikasi Ciptaan; dan }\end{array}\end{array}$ & $\begin{array}{l}\text { Reproduksi dan adaptasi; } \\
\text { komunikasi kepada publik; } \\
\text { penyewaan program komputer } \\
\text { asli atau versi salinannya; karya } \\
\text { audiovisual; } \\
\text { sinematografik dan perekaman } \\
\text { suara; memberikan keuntungan } \\
\text { yang timbul dari hak cipta } \\
\text { kepada pihak lainnya; } \\
\text { melisensikan hak-hak ekslusif } \\
\text { sebagaimana diuraikan di atas }\end{array}$ \\
\hline
\end{tabular}




$\begin{array}{ll}\text { penyewaan Ciptaan (Pasal } 9 \text { ayat } 1 & \text { ke orang lainnya tanpa atau } \\ \text { UUHC No. 28 Tahun 2014) } & \text { dengan seizin dari pencipta } \\ & \text { sepanjang kondisi seperti itu } \\ & \text { tidak akan ditentukan } \\ & \text { sedemikian rupa sehingga } \\ & \text { membatasi persaingan secara } \\ & \text { tidak adil. }\end{array}$

Dari contoh kasus-kasus merek dan hak cipta di atas, benang merah atas pengaturan pelindungan logo ditinjau dari hukum merek dan hak cipta di Indonesia dan Thailand adalah, pertama, pengaturan logo menurut perspektif hukum kekayaan intelektual di Indonesia dapat dilindungi oleh hukum hak merek dan hak cipta. Menurut penelitian ini, merek di Indonesia dapat diartikan sebagai penamaan yang dapat berupa tanda, kata, angka, logo atau lukisan, yang berfungsi sebagai sarana pembeda yang membedakan suatu produk atau jasa satu dengan lainnya yang digunakan dalam kegiatan perdagangan barang ataupun jasa. Bisa dibayangkan apabila satu produk dengan produk lainnya tidak diberikan nama merek maka pelanggan produk tersebut mengalami kesulitan dalam mengidentifikasi jenis produk yang dimaksudkan. Sama halnya dengan orang perseorangan, untuk memudahkan mengindentifikasi satu orang dengan orang lainnya adalah dengan menyebutkan nama seseorang tersebut.

Apalagi penduduk Indonesia yang jumlahnya kian bertambah dengan demikian semakin beragam tingkat kebutuhan konsumtif terhadap suatu produk atau jasa setiap waktunya, maka untuk memudahkan dalam membedakan produk atau jasa yang diproduksi atau dimiliki oleh suatu produsen adalah dengan diberikannya nama merek dan/atau lukisan yang dilekatkan pada kemasan produk atau jasa tersebut. Dengan banyaknya jenis variasi produk atau layanan jasa yang disuguhkan kepada para konsumen di Indonesia, produsen harus mengembangkan kreativitas tanpa batas dalam membangun mereknya agar dapat menarik perhatian konsumen. 
Berdasarkan penelitian ini, saat ini kecenderungan produsen menciptakan berbagai macam nama merek yang disertai dengan logo atau lukisan pada kemasan produk atau jasanya untuk mendapatkan perhatian dari para konsumennya. Sehingga, logo dalam pelindungan hukum merek adalah sebagai tanda pembeda yang berfungsi untuk membedakan produk atau jasa satu dengan lainnya dalam kegiatan perdagangan barang dan/atau jasa.

Sedangkan, logo atau lukisan dalam pelindungan rezim hukum hak cipta tercakup dalam pelindungan terhadap karya seni rupa. Dapat disimpulkan bahwasanya bentuk pelindungan terhadap logo atau lukisan yang dilindungi di bawah rezim hukum merek dan hak cipta dapat dibedakan secara tegas dan lugas.

Terdapat permasalahan ketika mekanisme pencatatan hak cipta sebagaimana diatur dalam Pasal 65 Undang-Undang Hak Cipta Nomor 28 Tahun 2014 (Pencatatan Ciptaan tidak dapat dilakukan terhadap seni lukis yang berupa logo atau tanda pembeda yang digunakan sebagai merek dalam perdagangan barang/jasa atau digunakan sebagai lambang organisasi, badan usaha, atau badan hukum). Namun, pengaturan yang sama tidak diatur di dalam UndangUndang Nomor 20 Tahun 2016 tentang Merek dan Indikasi Geografis. Oleh karenanya, akan menimbulkan berbagai permasalahan apabila suatu merek yang terdapat komponen $\operatorname{logo}$ atau lukisan di dalamnya mengandung atau menggunakan logo atau lukisan hasil karya ciptaan pihak lain yang sudah dicatatkan pada Kantor Ditjen KI.

Undang-Undang Hak Cipta di Indonesia secara tegas mengatur bahwasanya suatu ciptaan tidak dapat didaftar apabila merupakan logo atau tanda pembeda yang digunakan sebagai merek dalam perdagangan barang/jasa atau digunakan sebagai lambang organisasi, badan usaha, atau badan hukum. Sedangkan, pengaturan tersebut tidak terdapat dalam UndangUndang Hak Cipta di Thailand.

Undang-Undang Merek di Indonesia dan Thailand sama-sama belum memasukkan pengaturan bahwasanya suatu permohonan pendaftaran merek tidak dapat didaftarkan apabila merupakan logo atas hasil karya ciptaan yang telah 
dicatatkan pada masing-masing kantor KI di Indonesia dan Thailand.

\section{Simpulan}

Melalui penelitian ini, disharmoni pengaturan pelindungan logo sebagai suatu karya intelektual dalam rezim hukum merek dan hak cipta menimbulkan adanya ketidakpastian hukum. Oleh karenanya, dilakukan penelitian ini dengan cara memperbandingkan konsep hukum antara negara Indonesia dan Thailand dengan melihat pendekatan kasus yang hampir serupa yakni kasus pelanggaran hak cipta lukisan karakter MIFFY yang digunakan sebagai nama merek dagang "OJOSUN" bertujuan untuk mengefisiensikan dan mengoptimalkan pelindungan logo tersebut. Dengan demikian, perlu adanya suatu upaya harmonisasi pengaturan logo dalam perspektif hukum merek dan hak cipta di Indonesia untuk mewujudkan peraturan perundang-undangan kekayaan intelektual yang selaras, sesuai sehingga mewujudkan keadilan dan kepastian hukum.

\section{Daftar Pustaka}

\section{Buku}

Aaker, David A, 1991, Managing Brand Equity (Capitalizing on the Value of a Brand Name), USA: Simon \& Schuster Inc.

Amirulloh, Muhamad dan Muchtar, Helitha Novianty, 2016, Buku Ajar Hukum Kekayaan Intelektual, Cetakan Pertama, Bandung: Unpad Press.

Derclaye, Estelle (ed), 2017, Overlapping Rights, Handbook on Intellectual Property Rights, Oxford University Press, forthcoming.

Tjiptono, Fandy, 2014, Branding \& Brand Longevity di Indonesia, Yogyakarta: Andi Offset.

Gautama, Sudargo, 1977, Hukum Merek Indonesia, Pertama, Bandung: Alumni.

Indriyanto, Agung dan Yusnita, Irnie Mela, 2017, Aspek Hukum Pendaftaran Merek, Jakarta: Raja Grafindo Persada.

International Legal Counsellors Thailand Limited, 2017, Thailand Business Legal Handbook, Kesebelas, Thailand.

Jened, Rahmi, 2017, Hukum Merek dalam Era Global \& Integrasi Ekonomi, Cetakan Kedua, Jakarta: Kencana. 
Nicolina, Patricia F., 2007, Brand Management, Kedua, Jakarta: Prenada Media Group.

Sekar Sari, Christina Ariadne, 2017, Teknik Menganalisa Produk dan Merek Konsep dan Aplikasi pada Fast Moving Consumer Goods, Pertama, Jakarta: Gramedia Pustaka Utama.

Soekanto, Soerjono, 2015, Pengantar Penelitian Hukum, Tujuh Belas, Depok: Rajagrafindo Persada.

Sugianto Yasir; Machasin; Rambat Lupiyoadi, 2009, Intim dengan Pelanggan sebagai Basis Strategi Bersaing, Pertama, Jakarta: Lembaga Penerbit Fakultas Ekonomi Universitas Indonesia.

Utami, Subandini Nurtyas, 2014, Tinjauan Penerapan Klasifikasi Barang Dan Jasa Berdasarkan Nice Classification Dalam Rangka Pendaftaran Merek di Indonesia, Yogyakarta: Universitas Gadjah Mada.

World Intellectual Property Organization, 1993, Introduction to Trademark Law and Practice: The Basic Concept, Jenewa.

\section{Jurnal}

Achmad Chosyali, 2018, "Pelindungan Hukum Hak Cipta Buku Pengetahuan Ditinjau Dari Undang Undang Nomor 28 Tahun
2014 Tentang Hak Cipta”, Refleksi Hukum, Vol. 3, No. 1.

Amirulloh, Muhamad dan Kusumawati, Aneke Putri, 2014, Pelindungan Merek terhadap Framing, Meta Tag, dan Deep Linking Berdasarkan UU No. 15 Tahun 2001 tentang Merek dan Perbandingannya dengan Regulasi dan Praktik di Amerika Serikat, Padjadjaran Jurnal Ilmu Hukum, Volume 1 - No 3, diakses 20 Maret 2020: http://jurnal.unpad.ac.id/pjih /article/view/7087.

Angela Oscario, 2013, "Pentingnya Peran Logo Dalam Membangun Brand", HUMANIORA Vol.4 No.1 April 2013.

Calboli, Irene, 2014, Overlapping Copyright and Trademark Protection: A Call for Concern and Action, Illinois Law Review Slip Opinions, diakses 21 Maret 2020: https://scholarship.law.tamu. edu/cgi/viewcontent.cgi?arti $\mathrm{cle}=1612 \&$ context $=$ facschol ar.

Dendi Martha R, Sentot P.S, M. Zairul Alam, 2015, "Pelindungan Hukum Terhadap Pencipta Lagu Yang Belum Di Daftarkan Ke Drektorat Jendral Hak Kekayaan Intelektual (Analisis Pasal 40 Ayat 3 No. 28 Tahun 2014 Tentang Hak Cipta)", Jurnal Hukum, Juni 2015. 
Djoko Santoso dan Agung Sujatmiko, "Royalti Hak Cipta Sebagai Obyek Jaminan Fidusia", Masalah - Masalah Hukum, Jilid 46 No.3, Juli 2017, 198204.

Labetubun, Muchtar AH, "Penyelesaian Sengketa Hak Atas Logo (Suatu Kajian Overlapping Hak Cipta dan Merek)", Jurnal Hukum Acara Perdata ADHAPER, Vol. 5, No. 1, Januari - Juni 2019, 151-166.

Mamahit, Jisia, 2013, Pelindungan Hukum atas Merek dalam Perdagangan Barang dan Jasa, Lex Privatum, Vol. 1 No. 3, diakses 30 Maret 2020:

https://ejournal.unsrat.ac.id/i ndex.php/lexprivatum/article /view/3040.

Margono, Suyud, 2012, Prinsip Deklaratif Pendaftaran Hak Cipta: Kontradiksi Kaedah Pendaftaran Ciptaan dengan Asas Kepemilikan Publikasi Pertama Kali, Jurnal Rechtsvinding, Vol 1 Nomor 2, diakses 30 Maret 2020: https://rechtsvinding.bphn.g o.id/ejournal/index.php/jrv/a rticle/view/99.

Muhammad Fahmi Rois, Kholis Roisah, 2018, "Pelindungan Hukum Kekayaan Intelektual Kerajinan Kuningan Tumang”, Kanun Jurnal Ilmu Hukum, Vol. 20, No. 3, (Desember, 2018).
Prawiranegara, Boy dan Sardjono, Agus, 2015, Persinggungan Hak Cipta Dan Merek: Studi Kasus Sengketa Logo Badak Dan Sengketa Logo Natasha, Universitas Indonesia, diakses 3 April 2020: http://lib.ui.ac.id/naskahring kas/2015-09/S54485boy\%20prawiranegara

Rafianti, Laina, 2013, Perkembangan Hukum Merek di Indonesia, Fiat Justitia Jurnal Ilmu Hukum, Volume 7 No. 1, Januari-April.

R. Murjiyanto, 2016, "Konsep Kepemilikan Hak Atas Merek di Indonesia (Studi Pergeseran Sistem "Deklaratif" ke dalam Sistem "Konstitutif"), Jurnal Hukum IUS QUIA IUSTUM NO. 1 VOL. 24 JANUARI 2017.

Siti Hatikasari, 2018, "Esensi Pelindungan Hukum Dalam Sistem First To Announce Atas Karya Cipta", Supremasi Hukum : Jurnal Penelitian Hukum, Vol. 27, No. 2, Agustus 2018.

Sudjana, 2019, "Pembatasan Pelindungan Kekayaan Intelektual (Hak Cipta) dalam Perspektif Hak Asasi Manusia", Jurnal HAM, Volume 10, Nomor 1, Juli 2019.

Zainul Amin, 2018, "Penegakan Hukum Terhadap Hak Cipta Dalam Bidang Industri Kreatif Di Negara Kesatuan 
Republik Indonesia”, Mimbar Keadilan Jurnal Ilmu Hukum, Februari 2018.

\section{Peraturan Perundang-undangan}

Undang-Undang No. 28 Tahun 2014

Tentang Hak Cipta

(Republik Indonesia, 2014).

Undang-Undang No. 20 Tahun 2016

Tentang Merek dan Indikasi Geografis (Republik Indonesia, 2016).

Undang-Undang Merek Thailand (Trademark Act) B.E. 2534 (1991) serta Perubahannya Nomor 2 (1999) dan Nomor 3 (2016).

Undang-Undang Hak Cipta (Copyright Act) B.E. 2537 (1994) serta Perubahannya Nomor 2 (2015), Nomor 3 (2558) dan Nomor 4 (2018).

Penjelasan Undang-Undang No. 20 Tahun 2016 Tentang Merek dan Indikasi Geografis (Republik Indonesia, 2016).

Peraturan Pemerintah Nomor 67 Tahun $2016 \quad$ Tentang Pendaftaran Merek (Republik Indonesia, 2016).

\begin{tabular}{crr} 
Keputusan & Dirjen & \multicolumn{2}{c}{ Kekayaan } \\
Intelektual & Nomor & HKI- \\
02.HI.06.01 & Tahun & 2017 \\
tentang & & Formulir \\
Permohonan & & Pendaftaran \\
Merek. & &
\end{tabular}

Website tanpa author

https://thailandcourt.com/intellectualproperty-law-in-thailand, diakses 29 Maret 2020. https://www.smartlegalth.com diakses 29 Maret 2020.

$$
\begin{aligned}
& \text { Informasi Detail Perkara No. } \\
& \text { 2/Pdt.Sus- } \\
& \text { HKI/Cipta/2019/PN Niaga } \\
& \text { Mdn, diakses 30 Maret 2020: } \\
& \text { http://sipp.pn- } \\
& \text { medankota.go.id/index.php/ } \\
& \text { detil_perkara. }
\end{aligned}
$$

Sumber Database Kantor Ditjen Kekayaan Intelektual, Kementerian Hukum dan HAM, Republik Indonesia, diakses 30 Maret 2020: www.dgip.go.id.

\section{Website dengan author}

ASEAN Briefing, Mei 2016, "Trade Mark Law in Thailand: Guidelines for Registration and Enforcement", diakses 21 Maret 2020: https://www.aseanbriefing.c om/news/understandingthai-trademark-law/.

BisnisUKM, 2014, “Pentingnya Logo pada sebuah Kemasa Produk, diakses 19 November 2020: https://bisnisukm.com/penti ngnya-logo-pada-sebuahkemasan-produk.html

Calboli, Irene, 2014, “Overlapping Rights: When Works Become Brands (and What is Wrong With It)", diakses 30 Maret 2020: http://law.scu.edu/wpcontent.

"Issues of The IP Enforcement In Thailand", Phattarrasak Vannasaeng and Ruangsit Tankarnjananurak, diakses 
23 April 2020:

http://www.win-

cls.sakura.ne.jp/pdf/2/78-

82.pdf.

"7 Jenis Logo dan Penggunaannya", Rebecca, 21 Januari 2017, diakses 26 April 2020: https://www.decodeko.co.id/ blog/jenis-logo/.

"Keputusan Hakim Soal Sengketa Logo PSMS Medan", Victory Arrival Hutauruk, diakses 30 Maret 2020: https://medan.tribunnews.co m.

"Logo Can Be Protected As A Trademark And A Copyright In Thailand" Kowit Somwaiya dan Paramee Kerativitayana, LawPlus Ltd., January 2019, diakses 30 Maret 2020: https://www.lawplusitd.com /Article

"Logo PSMS Medan 1950 Dicaplok, Pencipta Meradang", Rio, diakses 30 Maret 2020: http://innews.co.id/logopsms-medan-.

"Making a Handbook for Intellectual Chambers of Commerce Property and Business Associations Work Setting Up Intellectual for Business Property Services", 2011, World Intellectual Property Organization, diakses 29 Maret 2020, https://wipo.int.smehttps://w ipo.int/about-ip.
"Membuat Sebuah Merek Pengantar Merek untuk Usaha Kecil dan Menengah", 2008, World Intellectual Property Organization (WIPO), diakses 26 Maret 2020: https:www.wipo.int/sme/.

Pentingnya Logo untuk Kepentingan Bisnis, Putri Fajrin, 2 Agustus 2019, diakses 16 November 2020: https://www.mbizmarket.co. $\mathrm{id} /$ news/logo-dan-perananpentingnya-untukkemajuan-bisnis/

"Sengketa Logo PSMS, Hakim Menangkan Gugatan Dr Mahyono, Batalkan Kepemilikan PT PESEMES", Nina $R$, accessed March 30, 2020, https://sumut.pojoksatu.id/b aca/sengketa-logo-psmshakim-menangkan-gugatandr-mahyono-batalkankepemilikan-pt-pesemes.

"Standards concerning the availability, scope and use of Intellectual Property Rights", World Trade Organization, accessed November 16, 2020: https://www.wto.org/english /docs_e/legal_e/27trips_04_e.htm\#2

"Trade Mark Law in Thailand: Guidelines for Registration and Enforcement", ASEAN Briefing, diakses 29 March 2020:

https://aseanbriefing.com/ne ws 